\title{
On Keynesian Economics and the Economics of Keynes after fifty years
}

\section{Pierrick Clerc \& Rodolphe Dos Santos Ferreira}

To cite this article: Pierrick Clerc \& Rodolphe Dos Santos Ferreira (2020) On Keynesian Economics and the Economics of Keynes after fifty years, The European Journal of the History of Economic Thought, 27:6, 919-937, DOI: 10.1080/09672567.2020.1817116

To link to this article: https://doi.org/10.1080/09672567.2020.1817116

\section{Published online: 03 Sep 2020.}

Submit your article to this journal $\widetilde{ }$

山 Article views: 165

Q View related articles ¿

View Crossmark data $\nearrow$ 


\title{
On Keynesian Economics and the Economics of Keynes after fifty years
}

\author{
Pierrick Clerc and Rodolphe Dos Santos Ferreira
}

\begin{abstract}
Axel Leijonhufvud's On Keynesian Economics and the Economics of Keynes (1968) definitely belongs to the category of "classic" books. Its message-decentralised economies are prone to large increases in unemployment since communication failures prevent the optimal coordination of private decisions-is by now well understood. In this paper, we argue that even though most commentators correctly identify this message, they overlook two crucial aspects of Leijonhufvud's demonstration. These aspects relate to what the author calls the "aggregative structure" and the "transaction structure" of macro-models. We show that the former type of structure plays a central role in the emergence of unemployment in the "Economics of Keynes", while the latter type of structure explains why unemployment is "involuntary".
\end{abstract}

\section{KEYWORDS}

History of macroeconomics; Leijonhufvud; Keynesian economics; coordination failures

\section{JEL CLASSIFICATION}

B22; E12

\section{Introduction}

The publication in 1968 of Axel Leijonhufvud's On Keynesian Economics and the Economics of Keynes was an important event for the history of economic analysis and for macroeconomic theory. It deeply changed our understanding of Keynes' theoretical contribution and of the nature of a Keynesian approach - with no quotation marks-to macroeconomic theorising. According to Michel De Vroey, "Leijonhufvud's depth of insights, as well as his mastery of Keynes's arcane argumentation, is still impressive today. A rare occurrence for a book that was mainly critical, Leijonhufvud prompted macroeconomists, especially young ones, to reassess the road taken by the first generation of Keynesian economists and to realise that alternative routes could be envisaged" (2016, 115).

In his interview with Brian Snowdon, Leijonhufvud summarises the message of his book as follows: "The book is essentially about the kind of information questions that do not occur in neoclassical Walrasian general equilibrium models. The issues I was dealing with had to do with how information and communication flow in the system so as to enable a coordinated solution to be achieved" (Leijonhufvud in Snowdon 2004, 123). Unfortunately, the author began his characterisation of the "revolutionary"

CONTACT Pierrick Clerc @ Pierrick.Clerc@live.fr @ HEC Liège and IRES—UCLouvain, Ottignies-Louvain-la-Neuve, Belgium; Rodolphe Dos Santos Ferreira BETA-University of Strasbourg, Strasbourg, France; Católica Lisbon School of Business and Economics, Lisbon, Portugal. 
element of the General Theory by the following well-known (and admittedly incorrect) statement: "In the Keynesian macrosystem the Marshallian ranking of price- and quantity-adjustment speeds is reversed" (Leijonhufvud 1968, 52). ${ }^{1}$ This idea was one of the major sources of the so-called "disequilibrium macroeconomics", self-proclaimed nonWalrasian but essentially moving "Walrasian tâtonnement" from prices to quantities, with prices kept provisionally fixed. Paradoxically, we thus end up with an extension to output prices of the wage rigidity that supposedly characterises the Keynesian approach, a "scandalously perpetuated falsehood" (Leijonhufvud in Snowdon 2004, 124).

The message of Leijonhufvud's book is by now well understood. To cite just two recent examples, written by prominent authors: "Leijonhufvud's message, therefore, was that in the absence of an auctioneer to ensure that appropriate prices prevail, there will be systematic coordination failures, involving goods, labour, and asset markets. These coordination failures arise not from rigidities, or any simple barrier to price adjustments, but from features that are inherent in any decentralised, dynamic economy in which decisions are made in real time" (Backhouse and Boianovsky 2013, 59); "Leijonhufvud's book was a book about a book, and its central message was that Keynes's book had been misread and its central message lost. [...] The lost message was that a decentralised economy faces information and signalling problems which make the coordination of economic agents' activities sub-optimal" (De Vroey 2016, 112).

In the present paper, we argue that while well-identified, this message involves crucial features which have nevertheless been largely ignored by macroeconomists (of both neoclassical and Keynesian brands) as well as by historians of the field. In the book, Leijonhufvud notably points out that "it is necessary to specify one's "dynamic structure," "aggregative structure," and "transaction structure," in dealing with (at least short-run) macrotheory or the confusion will be endless" (90, n.16, quotation marks and italics in the original). Most commentators of Leijonhufvud's work-including those previously mentioned-have focussed on the "dynamic structure", which concerns principally the reversal of the price- and quantity-adjustment speeds, and have neglected the "aggregative structure" and the "transaction structure". ${ }^{2}$ In this paper, we want instead to emphasise the central role played by these two latter structures, as determinants of the main differences between "Keynesian Economics" and the "Economics of Keynes".

The next section is devoted to the importance of the aggregative structure in Leijonhufvud's opus magnum. For Leijonhufvud, "the aggregation procedure is [...] as important in determining the properties of an economic model as are the assumptions made about the relationships between the aggregates" (111). He further claims about the aggregative structure of the standard income-expenditure model: It "is different from that of Keynes' model. In the chapters to follow, we will find repeatedly that

\footnotetext{
${ }^{1}$ References to Leijonhufvud (1968) will be restricted in the following to page numbers, indicated after the quotations.

${ }^{2}$ Neither the aggregative structure nor the transaction structure is considered in De Vroey (2016). Backhouse and Boianovsky (2013) make no reference to the transaction structure, and consider the aggregative structure only briefly in a single paragraph (57).
} 
important substantive differences between the two types of model derive from the different aggregation procedures employed" (De Vroey 2016). The differences in the aggregative structures of the "income-expenditure model" and of "Keynes' model" are examined in Chapter III of the book, and their implications can be found in Chapters III, IV and V. The problem is that the relationships between the alternative conclusions of the two models and their respective aggregative structures are not always made clear. ${ }^{3}$ Here, we try to make more explicit these relationships. We notably show that the aggregative structure that Leijonhufvud associates with Keynes' model is pivotal in the emergence-and in the persistence-of unemployment in Keynes' theory.

In Chapter II, Leijonhufvud notes that "considerable space is given in this study to discussing dynamic structure in terms of the ranking of adjustment speeds and aggregative structure in terms of index number theory," in contrast with the somewhat neglected transaction structure, difficult to handle "with economy and accuracy," but which "is no less important" (90, n.16). In Section 3, we stress two sets of features of the transaction structure which, according to Leijonhufvud, contribute to make unemployment "involuntary" in Keynes' theory. The first set concerns money as a medium of exchange, principally the monetary nature of the transaction going on in the labour market: "In economies relying on a means of payment, the excess demand for wage goods corresponding to an excess supply of labour is but 'notional'-it is not communicated to employers as effective demand for output. The resulting miseries are 'involuntary' all around” (98). The second set concerns money as a store of value, more precisely the saving-investment process and the role of financial markets. Among the nine "features" composing the relevant transaction structure which are proposed as examples by Leijonhufvud $(1968,398)$, three of them belong to this second set: saving and investment are decided by different groups of agents, transaction costs in securities markets are low enough to encourage speculation and no markets exist for forward trading in most specific goods. These features are clearly responsible for much of the coordination failures which generate and feed involuntary unemployment.

\section{Alternative aggregative structures, alternative implications}

Leijonhufvud has always developed a strong interest for the questions of aggregation. At the beginning of his $\mathrm{PhD}$ thesis, before focussing on "Keynes and the Keynesians", he thought about a debt-deflation mechanism to explain the Great Depression (before realising that Irving Fisher had preceded him). He especially wondered "why couldn't debt-deflation happen in any of the macro models that [he] had been taught or had read about? It could not happen because they all worked with consolidated balance sheets. In the Modigliani-Miller framework, for example, debts and claims just washed out" (Leijonhufvud in Snowdon 2004, 123). This question of "aggregation over transactors" is mentioned on several occasions in the 1968 book, ${ }^{4}$ although not tackled

\footnotetext{
${ }^{3}$ Leijonhufvud himself has recognised this weakness: "there is a lot in my 1968 book on aggregation which readers, I suppose, often fail to see the purpose of" (Leijonhufvud in Snowdon 2004, 123).

${ }^{4}$ For instance, at the beginning of Chapter III, Leijonhufvud stresses that "one of the most important issues of modern monetary theory revolves around the 'aggregation over transactors' problem. A seldom examined, though highly questionable, convention of contemporary monetary theory is the assumption that 'real' aggregate demand is independent of the 'real' value of intra private-sector financial contracts. Redistribution of real
} 
there. Indeed, "the assumption of 'no distribution effects' [... ] is a standard feature of income-expenditure models, and was only occasionally relaxed (in a most ad hoc manner) in the General Theory. Hence, it will be employed consistently throughout the following chapters" (116-117). Leijonhufvud will rather focus on the questions of "aggregation over goods" and "aggregation over assets".

In the book, he points out that "verbal expositions of the standard, closed-economy model generally refer to five aggregates: consumer goods; capital goods; labour services; money; government debt ('bonds')" (130, quotation marks in the original). However, both the income-expenditure model and Keynes's model comprise "only three variables which can be interpreted as price relations" (131, italics in the original). Hence, "one good has to go. The question is where" (132). In other words, two aggregates among the five just mentioned have to be lumped together-with four aggregates, no more than three relative prices are required.

Leijonhufvud stresses that in the income-expenditure model, consumption goods and capital goods are lumped together under the label "commodities". This model is therefore a "one-commodity model", with money and bonds as stores of value. Relying on the so-called "Hicks' theorem" (developed by John Hicks in Value and Capital), Leijonhufvud argues that the income-expenditure model implicitly assumes that the relative price of consumption goods and capital goods is constant over time. In Keynes' model, by contrast, capital goods and bonds are lumped together under the label "nonmoney assets" (held under the form of equity shares). It is a "two-commodity model", with money and non-money assets as stores of values. Keynes' model, in turn, implicitly assumes that the relative price of bonds and capital goods is constant. The "aggregative structure" of these two models can be represented as follows:

\section{Keynes's model}

Consumer goods

Non-money assets

Money

Labour services

\section{Income-expenditure model}

Commodities

Bonds

Money

Labour services

Leijonhufvud considers that the emergence and the persistence of unemployment, in Keynes' theory, result from the short-run inflexibility of the long-run interest rate. The actual (or "market") long rate would notably fail to decrease sufficiently in response to a negative shock on the Marginal Efficiency of Investment (MEI). Such a shock entails a decline in the real return on physical assets, i.e., a fall in the Wicksellian natural rate of interest. However, investors in the market for equities are not able to observe this rate (contrary to entrepreneurs). They can just make an estimate of its value, labelled "normal rate" by Keynes. These investors are assumed: (i) to have a speculative demand for money, which means that they increase their demand for money when they observe a tendency of the market rate to fall below the normal rate;

net worth between creditors and debtors, due to price-level movements, is assumed to have no qualitatively predictable effects on aggregate demand, output, and employment. These variables are assumed to depend, apart from current income, only on the variables contained in the private sector's consolidated balance sheet" (Leijonhufvud 1968, 116, italics in the original). 
(ii) to develop inelastic expectations when they estimate the natural rate, which means that the normal rate is quite insensitive to the observed variations in the market rate. Together, these two assumptions prevent the market rate from falling towards the new natural rate after a negative shock on the MEI. The resulting gap between the two interest rates implies a decline in the demand for capital goods, not offset by a corresponding increase in the demand for consumption goods. This fall in aggregate demand induces the emergence of unemployment, which persists as long as investors do not revise downward their estimate of the natural rate.

In this section, we show that the aggregative structure that Leijonhufvud associates with Keynes' model is critical in this story, on three grounds. ${ }^{5}$

\subsection{Interest-rate inflexibility vs interest-inelasticity of the saving- investment nexus}

According to Leijonhufvud, the main opposition between the "Economics of Keynes" and "Keynesian Economics" would be related to the role of interest-rate adjustments in the emergence of unemployment: "There is hardly a sharper contrast to be found between Keynes and the income-expenditure theorists than that between the two positions on this matter. [...] In the early income-expenditure literature, the emphasis is not on the short-run inflexibility of the interest rate. Apart from the Liquidity Trap case, the interest rate may vary 'all over' but, it was argued, interest effects on both saving and investment are at best of only secondary magnitude [... . In this view, the problem was not that the interest rate does not move, it was that such movements have no appreciable effects on the system's 'real' variables" (240). In the perspective drawn by these "Keynesians", therefore, investment and saving would be interest-inelastic, and their respective schedules would be very steep. ${ }^{6}$ Hence, a negative shock on the MEI would induce a large decline in the natural rate, which is very likely to fall below zero. Given that the market rate cannot be negative, a positive gap between these two rates emerges (leading to unemployment), even if the market rate quickly falls to zero.

Leijonhufvud argues that this alternative explanation is incompatible with the aggregative structure of Keynes' model: “The aggregative structure of this model leaves no room for elasticity pessimism” (Leijonhufvud 1967, 405-406). In Chapters III and IV of his book, he demonstrates that this aggregative structure implies that investment and (to a lesser extent) saving strongly depend on the long-run interest rate. The investment and saving schedules are thus very flat. A negative shock on the MEI therefore induces a rather limited decline in the natural rate, and a positive gap between the market and natural rates emerges only because the former is inflexible in the short run. At the same time, Leijonhufvud concedes that the "elasticity pessimism" explanation

\footnotetext{
${ }^{5}$ In Chapter III, Leijonhufvud also discusses the aggregative structure put forward by James Tobin in the model of his 1955 paper. There, Tobin proposed to lump together consumption goods and capital goods in a single commodity, and money and bonds in a single financial asset. Leijonhufvud makes clear that Tobin's distinction between "physical" and "financial" assets is the relevant one to deal with the "risks of price level changes" (148), which are "the most significant in the context of his work." On the other hand, he argues that the distinction between "short" and "long" assets involved in Keynes' model is the relevant one to deal with a "change in 'the' rate of interest" (ibid, italics in the original), which is "the characteristic event which does loom large in his thinking about the capital accounts" (ibid.).

${ }^{6}$ Leijonhufvud explicitly refers to Lawrence Klein and his Keynesian Revolution book.
} 
put forward by Keynesians is consistent with the aggregative structure of the incomeexpenditure model. This structure indeed implies that the interest-elasticity of investment and saving is weak. Keynesians are thus misled because they take the incomeexpenditure model as a faithful representation of Keynes' model.

The elasticity of investment with respect to the long-run interest rate is the object of the third chapter of the book. There, Leijonhufvud points out that since bonds and capital goods are lumped together in Keynes' model, "bond-streams and equity-streams are (to a satisfactory approximation) perfect substitutes to wealth-owners" (136). Consequently, the discount rate applied to the evaluation of income-streams accruing to physical capital moves one-to-one with the interest rate paid on bonds. In addition, "Keynes' 'representative' non-money asset is a long-term asset. Thus [...] the representative capital good is very durable" (135, italics in the original). As a result, the present value of income-streams accruing to physical capital is very sensitive to the discount rate applied. Together, these two features imply that "the interest-elasticity of investment is therefore necessarily significant, as a purely logical matter, in terms of Keynes' model" (42). ${ }^{7}$ In the income-expenditure model, by contrast, bond-streams and equitystreams are imperfect substitutes. Moreover, since capital goods are lumped together with consumption goods, "the representative capital good [...] is short-lived" (166). Hence, investment is necessarily weakly elastic with respect to the (long-run) interest rate.

Leijonhufvud devotes a large part of Chapter IV to the question of the interest-elasticity of consumption and saving in Keynes' model. He recognises that "the interpretation essayed in this chapter will consequently be more speculative than in the rest of our study" (43). Indeed, while Keynes provided numerous textual evidence leaving no doubt about the large interest-elasticity of investment in his theory, he fell far short of doing so for consumption and saving. Leijonhufvud therefore needs to make some reconstruction in order to answer this question. In this enterprise, he makes use of several concepts developed by Hicks in Value and Capital, and especially that of "average period" of streams.

Leijonhufvud first notes that, since capital goods and consumption goods are two different commodities in Keynes' model, their relative price is variable. In particular, this relative price increases with a fall in the (long-run) interest rate. ${ }^{8}$ It is also a key indicator of real net worth, because an increase in the price of capital goods in terms of consumption goods makes the owners of capital goods "feel richer" (in real terms). As a result, a fall in the interest rate induces a rise in real net worth, which in turn creates an incentive to increase consumption in all periods. On the other hand, a fall in the interest rate "also raises the 'present cost' of a given standard stream" (244) of consumption, which creates an incentive to reduce consumption in all periods. However, in Keynes' theory, capital goods are "very durable" while individuals are only

\footnotetext{
${ }^{7}$ So much so that "Keynes saw a need to argue that the interest-elasticity of investment will not be infinite" (167, italics in original).

${ }^{8}$ Indeed, the analysis of the interest-elasticity of investment has led to the conclusion that "a decline in the interest rate, in Keynes' model, does imply a very considerable increase in the demand price for capital goods" (166). Furthermore, since "adjustments in 'securities' markets are assumed to proceed faster than in other markets" (329), a fall in the interest rate generates an increase in the relative price of capital and consumption goods.
} 
"ephemeral". 9 This implies that the "average period" of income streams exceeds that of consumption streams. Hence, a fall in the interest rate produces a positive "wealth effect" which raises consumption in every period. ${ }^{10}$ Consumption and saving are therefore relatively interest-sensitive in Keynes' model. ${ }^{11}$ In the income-expenditure model, capital and consumption goods are lumped together in a single commodity. This means that their relative price is fixed, excluding any wealth effect. Consumption and saving are thus interest-inelastic. ${ }^{12}$

In summary, in Keynes' model “intertemporal price incentives are effective-changes in interest rates or expected future spot prices will significantly affect present behaviour" (392, italics in the original). Moreover, since in this model "changes in the interest rate imply changes in the relative price of the system's two commodities" (384, italics in the original), an inflexible (long-run) rate means that "relative values are wrong" (46, italics in the original). Instead, the aggregative structure of the incomeexpenditure model is such that "intertemporal price incentives were almost completely ineffective-neither savers nor investors respond to changes in interest rates" (161). In addition, in this one-commodity model "relative values are allowed little play" (133). Therefore, "Keynes' successors immediately reverted to an algebraic model devoid of relative prices and with only a single commodity aggregate-a model which showed no trace of the analytical problem that Keynes had wrestled with for a decade" (24).

\subsection{Keynes-effect and automatic reversion to full employment}

The aggregative structure of macro-models is also a crucial aspect of the question of the existence, in Keynes' theory, of a mechanism which could possibly allow the economic system to revert back to full employment. Don Patinkin notably argued that Keynes, by overlooking the real balance (or Pigou) effect, would have neglected such a mechanism. This omission would be related to the lack of influence, in the short run, of real net worth on consumption: "in his main discussion of the (short-run) consumption function [...] the possible influence of assets was not (and could not) even be considered" (Patinkin 1948, 555). As a result, a fall in the price level (triggered by a fall in nominal wages) would have no impact on consumption, and the economic system would not be able to return to full employment without policy intervention. Hence, "Keynes' critics insist that his theory is fatally flawed" (Leijonhufvud 1968, 330, italics in the original). ${ }^{13}$

\footnotetext{
9 The system that Keynes assumed "is a system wherein the social function of production is eternal and the individual households, in comparison, ephemeral. 'In the Long Run we are all dead,' but production goes on and the capital stock is maintained and handed down from generation to generation." (258)

10 "The present value of net worth increases in greater proportion than the present cost of the old consumption plan, and the consumption plan can thus be raised throughout." (45)

${ }^{11}$ Interest rates have an impact on consumption and saving only through the wealth effect because "Keynes regards the substitution effect of interest changes as 'open to a good deal of doubt,' as 'secondary and relatively unimportant' - a phrase which in his works means, in effect, that the relation is ruled out of consideration." (196)

12 Again, under the assumption (made by most "Keynesians") that the substitution effect is "secondary and relatively unimportant."

${ }^{13}$ Leijonhufvud stresses that Keynes, in several passages of the General Theory, seemed to assume a purely "inside" money system. This ambiguity notably led Johnson (1965) to claim that Keynes' theory "is guiltless of the charges brought against it by Pigou and elaborated by Patinkin and others if interpreted as applying to
} 
According to Leijonhufvud, "Patinkin's critique is entirely to the point in relation to the 'standard' income-expenditure model. [... ] But with regard to the General Theory, his critique is misconceived. Keynes was not a "Keynesian"' (327). Indeed, we have seen that in Keynes' model, real net worth does have an impact on (short-run) consumption. A general deflation increases the real supply of money, which should (theoretically) reduce interest rates. This fall in interest rates generates a positive wealth effect which raises consumption. The fall in interest rates also stimulates investment. This indirect increase in aggregate demand resulting from an all-around deflation is known as the "Keynes-effect". ${ }^{14}$ With this effect, Keynes' model thus involves a mechanism that could allow the economic system to automatically revert to full employment: "With the 'Keynes-effect' Keynes conceded that, as a matter of logic, deflation could work" (324, italics in the original).

Patinkin and other critics of Keynes did not perceive the Keynes-effect "because they entirely misunderstand the structure of the model to which his argument refers" (324). In Money, Interest, and Prices (1965), Patinkin used a model which "is of the same aggregative structure as the income-expenditure model [...]. He discussed the General Theory with reference to this model" (327). Once again, the income-expenditure model is (wrongly) taken as a faithful representation of Keynes' model. ${ }^{15}$ And in the former model, the Keynes-effect cannot occur since consumption and investment are interest-inelastic. Hence, "the Neo-classicists refuse to take the Keynes-effect seriously. When Keynes tenders this effect in recognition of the possible benefits of deflation, he is received as a Greek bearing gifts. This suspicious attitude, of course, is based on the belief that Keynes shared with the income-expenditure school the assumption that both consumption and investment expenditures are virtually completely interestinelastic. If that were true, the Keynes-effect would indeed be a sham. But we know this belief to be unfounded" (330).

In Keynes' theory, on the other hand, the economic system does not return to full employment without policy intervention. However, this failure does not mean that the underlying mechanism is lacking. The persistence of unemployment is rather the manifestation that some forces impede the work of the Keynes-effect. These forces are again to be found on the side of investors in the securities market, who prevent the long-run interest rate from falling even in presence of wage and price deflation: "For reductions

\footnotetext{
an inside-money world" (8). Nevertheless, Leijonhufvud concurs with Patinkin (1965) on the fact that "Keynes' system does contain some 'outside' money" $(1968,325)$. He therefore recognises that Keynes' theory could be prone to the criticism raised by Patinkin. The distinction between inside and outside money, due to the seminal contribution of Gurley and Shaw (1960), is very important in Leijonhufvud's eyes. This relates to his strong interest (that we have pointed out previously) for the debt-deflation mechanism. In Chapter II, dealing with the "dynamic structure" of macro models, he especially notes that a "purely inside money system might 'implode' if the initial shock is heavy enough to set off a chain of defaults" (86). He then cites Irving Fisher's 1933 paper and argues that "One of the most disturbing features of the consolidated balance-sheet models, which dominate contemporary monetary theory, is that they are incapable of generating the debtdeflation process sketched by Fisher" (ibid, n.10). However, the 'no distribution effects' assumption made for the whole book prevented him from pursuing the analysis further.

${ }^{14}$ In the literature, the Keynes-effect usually refers to the increase in investment-and only in investmentstemming from a general fall in prices. However, Leijonhufvud defines this effect as "an effect on aggregate demand (i.e., on both consumption and investment) due [...] to all-around deflation" (325, italics in the original).

${ }^{15}$ Both models, however, involve inside and outside money.
} 
in the interest rate to contribute towards pushing the system back towards full employment, one must instead await the much slower process of a gradual revision of expectations about future long rates which will reduce the 'speculative demand for money' [...] But, in the shorter run, no such deviation-counteracting effects can be expected, whatever the interest-elasticity of expenditures" (183).

\subsection{The behaviour of investors in financial markets}

In Keynes' theory, the behaviour of investors in the market for equity shares is a key ingredient in the emergence (as well as in the persistence) of unemployment. More precisely, two assumptions characterising this behaviour are actually crucial: (i) existence of a speculative demand for money; (ii) inelasticity of the expectations with respect to the natural rate of interest.

These two assumptions were criticised by later "Keynesians" 16 from the perspective of models (notably Baumol 1952 and Tobin 1956) belonging to the "post-Keynesian monetary theory" (368). Here, we show that the aggregative structure of Keynes' model provides some rationale for both assumptions. For the purposes at hand, it is important to recall that this model is "a system where long-lived augmentable capital goods comprise the dominant store of value" (373, italics added).

\subsubsection{Aggregative structure and speculative demand for money}

In Keynes' theory, the speculative demand for money means that the demand for money is a decreasing function of the gap between the market and the "normal" rate of interest. Investors notably hold more money when the market rate falls below the normal rate: anticipating that such a fall will be only transitory, these investors (Keynes' "bear speculators") immediately sell their securities (against money) in order to avoid the capital losses associated with the future increase in the market rate.

Since capital goods (held under the form of equity shares) are long-lived in Keynes' model, their price is highly sensitive to interest-rates movements. An increase in the market interest rate thus induces a large drop in this price. As a result, a massive sale of equity shares-triggered by an expected increase in the market rate-seems justified in this context.

By contrast, “in the more recent 'Keynesian' literature, the microtheory of money demand is usually developed in terms of individual transactor choices between means of payment and the nearest money substitute" (355). Hence, "the perspective is 'foreshortened'-instead of 'money' and a very long-lived asset, the structure is represented by two assets very close to the short end" (356). In the latter case, the price of "the nearest money substitute" is necessarily weakly sensitive to interest-rates movements. An expected increase in the market rate will induce only a small drop in this price. A massive sale of such an asset is therefore difficult to justify in this perspective.

\footnotetext{
${ }^{16}$ Especially by Tobin (1958).
} 


\subsubsection{Aggregative structure and inelastic expectations}

The assumption of investors' inelastic expectations, in Keynes' theory, means that investors are not influenced by the variations in the market interest rate when they try to estimate the natural rate. ${ }^{17}$ They especially do not revise downward this estimate (i.e., the "normal" rate) when they observe a fall of the market rate below it. In other words, investors do not revise upward what they perceive as the "normal" price of assets when they observe a rise in the market price above this estimate.

Given that in Keynes' model "non-money assets" are (claims on) physical assets, we should refer to "Keynes' analysis of pricing in the market for a good of which considerable stocks are held, though carrying costs are relatively high" (374). In this latter analysis, Keynes' discussion "presumes the existence of a hypothetical 'normal price' determined by real forces-namely, the price which equates flow-demand and flowsupply in the longer run" (ibid). In the case of the aggregate stock of Fixed Capital, "there exists such a hypothetical 'normal price' consistent in the long run with the basic real determinants of Productivity and Thrift" (ibid). The normal price of capital goods should therefore be relatively stable through time, and investors have some reasons to view "a general rise in the price of income-streams with "inelastic suspicion"” (372).

Moreover, the "augmentable" nature of capital goods means that their production increases with their price. ${ }^{18}$ This feature has the important implication that the normal price of capital goods cannot rise towards very high levels. If such a rise happened, indeed, the resulting increase in the capital stock would immediately put downward pressure on this price ${ }^{19}$ since "excessive investment would before long cause holding yields to be negative" (374). Thus, "it is anything but unreasonable to assume that [... ] there exist some potential prices so high that their emergence would not be regarded by investors with an attitude of "bland unit-elasticity" (375). In a nutshell, "far from being a special case, inelastic expectations must in this context be the general case" (373).

In the models developed by the "post-Keynesian approach" of money demand, instead, there are no "real forces" producing a stable normal price for the "alternative monetary assets" (371). In addition, these assets are not augmentable since "it is not necessarily the case that the rate of change in the stock of "outside" financial assets depends closely or uniquely (or even positively) upon the current price which emerges in the market" (372-373). Hence, investors have no reasons to form inelastic expectations in the context of these models.

\section{The transaction structure and the theory of involuntary unemployment}

In section 3 of chapter II of his book, a section which was not part of his dissertation, Leijonhufvud stresses the fact that "the dynamic properties of an economic system depend upon what [he calls] its 'transaction structure'. That labour services are sold for

\footnotetext{
17 The concept of 'elasticity of expectations' was coined by Hicks (1939).

18 "The non-money store of value is augmentable. The higher its current price, the higher the flow-rate of net output." (373).

19 "The faster the rate growth of the capital stock, therefore, the faster the rate at which the 'real price' per unit will decline." (373-374).
} 
money and that households obtain their consumption goods in exchange for money is one aspect of the transaction structure of Keynes' system. Another, equally important, lies in the postulate that savers and investors are "not the same persons"' (90, italics in the original). In this section, we will take successively these two aspects of the transaction structure of Keynes' model and discuss their role in generating effective demand failures as well as intertemporal coordination failures.

\subsection{Money as a medium of exchange and effective demand failures}

The first aspect of the transaction structure of Keynes' model is linked to the function of money as a medium of exchange. The fact that "all exchanges involve money on one side of the transaction" (90, italics in the original) is a key property to explain the emergence of involuntary unemployment and the amplification of the effects of an initial demand shock (the multiplier).

\subsubsection{Offering labour for money: the involuntariness of unemployment}

The transaction structure of Keynes' model is first of all characterised by the feature that "the workers looking for jobs ask for money, not for commodities. Their notional demand for commodities is not communicated to producers; not being able to perceive this demand for their products, producers will not be willing to absorb the excess supply of labour at a wage corresponding to the real wage that would "solve" the Walrasian problem above. The fact that there exists a potential barter bargain of goods for labour services that would be mutually agreeable to producers as a group and labour as a group is irrelevant to the motion of the system" (90, italics in the original).

This crucial feature of the transaction structure opens the way to Keynes' distinction between voluntary and involuntary unemployment. The former results from an assumed refusal (in particular by "producers as a group and labour as a group") to accept the "barter bargain of goods for labour services" that would balance the labour market. The latter results from a communication (hence a coordination) default: an effective demand failure. "The significance of his discussion of involuntary unemployment will be entirely missed unless one sees quite clearly that Keynes did not seek to assign 'blame' to anyone or any group. Neither individually nor collectively do the transactors of the system that he dealt with 'refuse to cooperate' in the way that a Classical economist would find 'proper"' (93, italics in the original).

Keynes' definition of involuntary unemployment, which "has been regarded as most tortuously contrived by most later interpreters" (94) appears simple and clear when read through Leijonhufvud's lens. To recall, according to Keynes, "men are involuntarily unemployed if, in the event of a small rise in the price of wage-goods relatively to the money-wage, both the aggregate supply of labour willing to work for the current moneywage and the aggregate demand for it at that wage would be greater than the existing volume of employment" (Keynes 1936, 15; italics in the original). As a first observation on this definition, Leijonhufvud identifies a thought-experiment testing both labour and producers "for their willingness to cooperate in the way that the Classical theory of competitive markets would have them do" (94). Indeed, "were producers to act otherwise, their 'volition' would be to blame, in which case unemployment would not be 
'involuntary' in Keynes' sense. And workers, of course, are being tested for their willingness to take a real wage cut in order to become re-employed" (Keynes 1936, italics in the original).

Leijonhufvud later conceded that "the term, without a doubt, is one of the most unfortunate new coinages in the history of economics. This does not mean that the problem to which the term refers is therefore nonsensical" (Leijonhufvud 2000, 18). However, one may wonder if the term chosen by Keynes is indeed inadequate. The problem is rather that the terms voluntary and involuntary have been systematically understood at the individual level. "In today's textbooks 'involuntary' generally means simply that the individual worker has no choice because unions or minimum wage laws stand in his way. [...] Modern Keynesians tend to save the notion of 'involuntariness' by transferring the blame of the 'refusal to accept a reward corresponding to the marginal product' from the individual to unions, monopolies, or governments. Keynes lumped all the above three categories of unemployment into 'voluntary' unemployment and paid no further attention to them or to their causes" (93, italics in the original).

The second observation that Leijonhufvud makes about Keynes' definition of involuntary unemployment is that the test involving a cut in real wages refers to a rise in the price of wage goods rather than to a decline in money wages, although both are equivalent from a partial equilibrium standpoint or, as a matter of fact, from a Walrasian general equilibrium standpoint, with perfect contemporaneity and transparency of all price adjustments. The involuntariness of the unemployment contemplated in the General Theory cannot be separated from the transaction structure characterising the employment relation nor considered outside the approach of general equilibrium with dispersed information and imperfect coordination supposedly underlying Keynes' analysis.

For Leijonhufvud, after a careful rereading of the often disregarded chapter 2 of the General Theory, 'it was clear what Keynes' definition of 'involuntary unemployment' meant and why he had phrased it in such a seemingly awkward, contrived way. It was clear why he harped on Professor Pigou treating the wage-bargain as if it were a barter bargain when he (Pigou) knew it was a money bargain. It was clear what were Keynes objections to Say's Law (unemployed labour is not an effective demand for wage goods, and current saving does not constitute effective demand for future consumption)" (Leijonhufvud 1988, 212).

It was however only more than one decade after the publication of his book that Leijonhufvud could find, in previously unpublished material of Keynes' Collected Writings (vol. 29, 1980), clear textual evidence for the link between the transaction structure and the involuntariness of unemployment. He found it in the distinction between "a Co-operative and an Entrepreneur Economy" made in a discarded introduction to the General Theory: "Keynes' 'Co-operative Economy' [...] was one in which labour is bartered for goods, so that the supply of labour is always an effective demand for goods. In his 'Entrepreneur Economy' the Clowerian rule applies: labour buys money and money buys goods but labour does not buy goods. In the entrepreneur economy, therefore, effective demand failures are possible and so, consequently, is 'involuntary unemployment'” (Leijonhufvud, 1983, n.31). 


\subsubsection{Offering money for goods: the multiplier as an illiquidity phenomenon}

That labour is offered for money, not directly for goods, explains why an excess supply of labour is not automatically compensated by an effective demand for goods-a situation which opens the way to the emergence of involuntary unemployment. That goods are offered for money, not for wealth, including physical and human capital, explains why unemployed workers must curtail their consumption even when their wealth is not severely affected by their current and supposedly temporary unemployment status-a situation which opens the way to Keynes' multiplier. In his IEA Lecture (1969), Leijonhufvud acknowledges that the permanent income or life-cycle hypotheses do not imply that unemployed workers should necessarily cut their expenditures. Hence, a deviation-amplifying process-and then a persistent state of involuntary unemployment-cannot develop under such hypotheses.

Keynes' multiplier can however be reconciled with these hypotheses if we look at it "as an illiquidity phenomenon" (Leijonhufvud 1969, 44, italics in the original). "To borrow against future labour earnings [... can frequently be done only at terms which render it a very expensive way of turning human capital into ready purchasing power. Similarly, those components of his net worth that are in the form of physical capital are generally 'illiquid' too-they cannot be turned into cash without incurring what the individual will regard as a 'capital loss'. Borrowing with such assets as collateral is also an expensive proposition. We may thus envisage an individual who, while he regards his 'wealth' as in itself justifying a maintenance of accustomed living standards, finds that no component of his net worth can be realised at a market price that meets the reservation price he puts on it" (Leijonhufvud 1969, 43-44; quotation marks in the original).

Since "the multiplier emerges in this analysis as an illiquidity phenomenon", "we should not expect [it] to take hold in a recession as long as unemployed households still have a 'cushion' of liquid assets, such as saving deposits" (Leijonhufvud 1969, 44). "Considering a disequilibrium situation diagnosed as due to excessively pessimistic entrepreneurial expectations", we should thus conclude that "producers' demand forecasts could not remain so far off target without any tendency towards self-correction except when the consumption demands of unemployed are in large measure 'ineffective', i.e., except when the feedback of the relevant market signals is interrupted. [...] Communication failures of [serious] magnitude [...] emerge as products of 'liquidity crises" (Leijonhufvud 1969, 44-45; italics and quotation marks in the original).

This analysis allows Leijonhufvud to conclude: "By pursuing Keynes' analysis we have ended up with an essentially 'monetary' view of Great Depressions. In a very general sense, at least, quantity theorists and Keynesians should be able to agree on one thing-how great disasters are fashioned. On one view or the other, the system becomes prone to them only when it has first been squeezed dry of "liquidity"' (Leijonhufvud 1969; quotation marks in the original).

\subsection{Money as a reserve of value and intertemporal coordination failures}

The second aspect of the transaction structure of Keynes' system relates to the store-ofvalue function of money: investors' speculative demand for money is indeed one of the 
sources of what Leijonhufvud will later present as an intertemporal effective demand failure (Leijonhufvud 1998, 179). It comprehends however several features, not all directly connected with money, but all involving coordination of intertemporal decisions. This second aspect is assessed as "equally important" when compared with the first (making money appear on one side of each transaction), but this is rather an understatement. Thirty years after the publication of his book, Leijonhufvud would indeed write: "There are not many obvious traces of the debt deflation problem in my 1968 book, but my particular path to Keynes explains why I discuss information assumptions so much and why I also differ from Clower in regarding the intertemporal coordination issue (the saving-investment business) as the core problem in Keynes as well as central to macroeconomics in general" (Leijonhufvud 1998, 175; our emphasis).

Let us recall the three major features of the transaction structure, listed by Leijonhufvud, that correspond to this second aspect. The first is that "saving decisions and investment decisions are vested in largely non-overlapping groups of people" (398). This is clearly far from the imaginary world where the representative consumer is responsible for both saving and investment decisions, but also from the ArrowDebreu economy where those decisions, although tentatively taken by different agents, are perfectly coordinated by the financial markets as if an auctioneer were in charge of the whole system.

The second feature is that "savers are generally not willing to enter into contracts for the future delivery of specific consumption goods, so that no markets exist for forward trading in such goods" (Leijonhufvud 1998). ${ }^{20}$ The inexistence of many-mostfutures markets is of course a serious obstacle for the coordination of intertemporal decisions, an obstacle stressed by Keynes in his parable of the postponed dinner, at the beginning of chapter 16 of the General Theory. It is true that for new Walrasians, "it does not matter [...] whether or not the intertemporal markets exist to transmit price information. For those that do not exist, we simply substitute the rationally expected prices. And the learning of these rational expectations themselves is by convention relegated to the past as transient dynamics that (one presumes) have long since died down" (Leijonhufvud 1998, 183). By contrast, "the Keynesian effective demand failures are communication failures occurring in a system where people adapt their behaviour to the information they currently receive" (Leijonhufvud 1998; our emphasis), so that missing markets are indeed a problem in a world where equilibrium is not offered out of hand but attained only adaptively.

The third feature is that "transactions costs, including costs of acquiring price information, are relatively low in securities markets, making it inexpensive for individual

\footnotetext{
${ }^{20}$ More generally and as suggested by Hicks in Value and Capital-certainly one of the major sources of inspiration of Leijonhufvud-“it is uncertainty of the future, and the desire to keep one's hands free to meet that uncertainty, which limit the extent of forward trading under capitalism" (Hicks 1939, 139). "Owing to the limitations of forward trading, [the model of a 'Spot Economy'] is not really a very drastic simplification of reality," whereas the model of a 'Futures Economy" "can have no claims to be a good approximation to reality, for it would only be in a world where uncertainty was absent and all expectations definite, that everything could be fixed up in advance" (Hicks 1939, 140). Accordingly, Hicks concentrates his analysis on Temporary Equilibrium (which does not extend to the coordination of intertemporal decisions) rather than on Equilibrium over Time, requiring that "the change in prices which occurs is that which was expected" (Hicks $1939,132)$ and hence assuming perfect intertemporal coordination, through futures markets or else through perfect foresight.
} 
transactors to move in or out of such assets" (398), in other words, making it inexpensive to speculate. The way is thus opened to the diversion of financial markets from their intertemporal coordination function to "the speculative activity which stabilises yields and prevents the interest rate from adjusting in a 'Classical' manner" (47).

\section{Conclusion}

In this paper, we have argued that the aggregative structure and the transaction structure are crucial to understand the emergence and persistence of involuntary unemployment in Leijonhufvud's "Economics of Keynes". We have not, however, investigated the reasons why the importance of both types of structure has been largely overlooked. Providing such reasons can only be (at best) speculative. We nevertheless believe that the nature of the potential explanations is specific to each type of structure.

The neglect of the aggregative structure is most probably related to the lack of formalisation of Leijonhuvfud's book. ${ }^{21}$ While we completely concur with Peter Howitt when he notes that "it is remarkable that a book without a single equation could have such a major influence on a discipline dominated by mathematical modeling" (2002, 7), the lack of formalisation becomes a limit when it comes to compare the aggregative structures of different models. In such a context, an analysis conducted in a purely literary form becomes particularly difficult to follow, notably when it spreads over no less than three chapters. The reader can easily fail to make a clear connection between the implications of different models and their respective aggregative structures.

The lack of consideration for the transaction structure is rather to be found on the side of the suppression (or the repression, in the Freudian sense) of the concept of "involuntary unemployment", or else of its downgrading to the level of individual decisions where it is opposed to "voluntary unemployment" viewed as leisure chosen by the individual worker. ${ }^{22}$ Twenty years after the publication of his book, Leijonhufvud could write that "there is to this day no alternative interpretation of Keynes' chapter 2 in the literature which makes coherent sense of it. Almost all authors simply ignore Keynes' elaborate definition of involuntary unemployment and substitute their own opinion of what the words might usefully (or, in the case of Lucas, uselessly) mean; most of them end up thus labelling some concept of unemployment that Keynes went to the pains of explicitly listing as "voluntary" (Leijonhufvud 1988, 212). After sixteen more years, Leijonhufvud could make essentially the same statement: “To Lucas and other 'Moderns', 'involuntariness' is utter nonsense in any properly formulated choicetheoretical context. A number of Keynesians or neo-Keynesians-add, for example, Frank Hahn and Joe Stiglitz to your list-protest, arguing that for some class or other of workers' opportunity sets, the use of the term makes common sense. Neither side in this exchange is using 'involuntary unemployment' in a sense that has the remotest connection to what Keynes was talking about" (Leijonhufvud in Snowdon 2004, 133). Curiously, or perhaps significantly, the same observation still applies fifty years after

\footnotetext{
${ }^{21}$ One of us has suggested a formalisation of the economics of Keynes, at least partly along Leijonhufvud's lines (Dos Santos Ferreira 2014).

${ }^{22}$ Even some prominent names belonging to Keynes' "Circus," such as Joan Robinson (1937) or Richard Kahn (1976), have interpreted the concept of "involuntary unemployment" in this downgraded sense.
} 
the publication of Leijonhufvud's book. Hence, as the transaction structure is especially critical to explain the "involuntariness" of unemployment, rejecting the latter quite naturally leads to disregarding the former.

Let us finally say some words on the posterity of Leijonhufvud's opus magnum. The book has long been considered a forerunner of "disequilibrium macroeconomics", developed in the 1970s in the wake of Barro and Grossman (1971) seminal contribution. ${ }^{23}$ However, Leijonhufvud has expressed strong criticism towards this research programme, on two grounds. First, it was rooted in the Walrasian (or "Modern") tradition. ${ }^{24}$ According to Leijonhufvud, this tradition would make three assumptions about economic agents: (a) they always succeed in maximising utility or profit, so that "the statement that they maximise utility or profit is taken to be a proposition about realised performance, not just intention or ambition" (Leijonhufvud 1998, 171); (b) their behaviour is "ex ante optimizing", not adaptive; (c) their cognitive competence is characterised as "unbounded rationality." No need to say that such a conception of the economic agent is at odds with Leijonhufvud's. Secondly, disequilibrium macroeconomics explained the emergence of unemployment by postulating price and wage rigidities. ${ }^{25}$ It is worth mentioning that Leijonhufvud would later criticise the various brands of "New Keynesian Economics" (from the kind of nominal stickiness put forward by Fischer 1977 and Phelps and Taylor 1977 to DSGE modelling) along the same lines. ${ }^{26}$

Since the late 1970s, references to Leijonhufvud's book-and more generally to the themes he developed there and in the 1970s-have gradually fallen. The rational expectations "revolution" certainly explains this declining influence, for reasons notably expounded by Howitt (1984). Howitt first observed that "Leijonhufvud's approach shares a great deal with modern rational expectations theory" (442), especially "in its focus upon signal extraction problems." However, there would be two crucial differences between them. The first "concerns the stability assumptions imbedded in the rational expectations approach. Lucas [...] proceeds as if [the process of learning] has somehow managed to converge upon a set of consistent beliefs," whereas Leijonhufvud "argues that serious departures from full information are usually the result of one group of agents forming beliefs which are inconsistent with those of other agents" (430). The second difference "is revealed in Lucas' (1980a) lucid account of the main methodological advantage of his research strategy" (443). This strategy neglects the process by which markets reach equilibrium, whereas Leijonhufvud's approach "is to

\footnotetext{
${ }^{23}$ Barro and Grossman (1976) pointed out the influence of Leijonhufvud's book on this approach: "earlier efforts by other authors, especially Patinkin (1965) and Clower (1965), along lines which seemed promising had apparently made little impact on the profession. However, the publication of the argumentative book by Leijonhufvud (1968) did succeed in stimulating interest in these issues." (xi)

24 "The way in which I (and Robert Clower) couched the 'microfoundations of macro' problem was in some degree responsible for the attempts by Barro and Grossman, Benassy, Malinvaud, Frank Fisher and others to construct 'Keynesian' models on neo-walrasian optimizing foundations. This did not seem a promising way to go and I took no part in this development" (Leijonhufvud 1998, 175).

25 "Note that there are two types of theoretical structures that will not allow you to analyze the EDF (Effective Demand Failures) question: (1) The fix-price GE (General Equilibrium) models, commonly called 'Keynesian disequilibrium' models. (2) The New Classical models. The question 'what ED's (Effective Demand) govern price adjustments' does not make sense either in models where prices do not adjust or in models where there are no meaningful excess demands. So the EDF question is an example of a question, central to Keynesian theory, that is excluded from analysis by current methodologies" (Leijonhufvud 1989, 18, parentheses added).

${ }^{26}$ See Trautwein (2020) for a review of Leijonhufvud's criticism towards New Keynesian Economics.
} 
regard 'market adjustment' as the principal phenomenon to be explained." Nearly twenty years later, Howitt (2002) would restate his analysis and conclude: "the rational-expectations revolution, which started from a parable that nicely embodies Leijonhufvud's cybernetic vision, ended up taking the central issue Leijonhufvud was addressing almost completely out of the realm of professional discourse" (9).

Recently, however, a growing part of the literature has questioned the dominance of rational expectations on the basis of arguments developed in Leijonhufvud's book. These arguments relate to the two differences between Leijonhufvud's approach and the "modern rational expectations theory" stressed by Howitt (1984). A first strand of the literature emphasises the "imperfect common knowledge" of agents acting on different markets, and the importance of their "higher-order beliefs". ${ }^{27}$ Nevertheless, references to Leijonhufvud's work turn out to be nil by the authors arguing along these lines. ${ }^{28}$ A second group of papers seeks to explain how the equilibrium (conceived as a "state of rest") is attained on various markets, and advocates an "agent-based" approach to achieve this aim. Such an approach is clearly rooted in what Leijonhufvud (1998) termed the "Classical" tradition. In this latter, economic agents would have three main characteristics: (a') their motivation is the maximisation of utility (or profit), but it is only “an assumption about motivation, not realization" (170); (b') their behaviour is adaptive; (c') their rationality is bounded, but agents are "capable of learning" (171). Leijonhufvud has promoted this evolutionary perspective in several contributions, ${ }^{29}$ but also through the research programme on computational economics initiated at UCLA in the early 1990s under his impulsion. Obviously, the "cybernetic" approach suggested in his book belongs to this "Classical" tradition, and some proponents of agent-based macroeconomics refer to Leijonhufvud's work. ${ }^{30}$ It remains to be seen if agent-based macroeconomics will succeed in challenging the mainstream of macroeconomic theorising.

\section{Acknowledgements}

We would like to thank Michel De Vroey, Hans-Michael Trautwein and two anonymous referees for valuable comments and suggestions. The views expressed in this article are ours and do not necessarily reflect those of our respective institutions.

\section{Disclosure statement}

No potential conflict of interest was reported by the author(s).

\footnotetext{
27 The various papers of Stephen Morris and Hyun Song Shin, starting in the mid-1990s (see e.g., Morris and Shin 1995, 1997), as well as Woodford (2002) and Sims (2003), initiated these developments. Angeletos and Lian (2016), in a chapter (entitled "Incomplete Information in Macroeconomics: Accommodating Frictions in Coordination") of the second edition of the Handbook of Macroeconomics, provide a survey.

${ }^{28}$ Note that references to Leijonhufvud were already scarce in the 'coordination failures' literature of the 1980s (exemplified by Diamond 1982 or Cooper and John 1988).

${ }^{29}$ See, in particular, Leijonhufvud $(1993,1995,2006)$. One of us has provided a more detailed account of Leijonhufvud's evolutionary perspective (Clerc 2019).

${ }^{30}$ See the conclusion of Trautwein (2020) for references.
} 


\section{ORCID}

Rodolphe Dos Santos Ferreira (D) http://orcid.org/0000-0001-6966-281X

\section{References}

Angeletos, G. M., and C. Lian. 2016. "Incomplete Information in Macroeconomics: Accommodating Frictions in Coordination." In Handbook of Macroeconomics. 2nd ed, chapter 14, edited by John B. Taylor and Harald Uhlig. Amsterdam, Netherlands: Elsevier Science, North Holland.

Backhouse, R. E., and M. Boianovsky. 2013. Transforming Modern Macroeconomics: Exploring Disequilibrium Microfoundations, 1956-2003. Cambridge, UK: Cambridge University Press.

Barro, R. J., and H. I. Grossman. 1971. "A General Disequilibrium Model of Income and Employment." The American Economic Review 61 (1): 82-93.

Barro, R. J., and H. I. Grossman. 1976. Money, Employment, and Inflation. Cambridge, UK: Cambridge University Press.

Baumol, W. J. 1952. "The Transactions Demand for Cash: An Inventory Theoretic Approach." The Quarterly Journal of Economics 66 (4): 545-556. doi:10.2307/1882104.

Clerc, P. 2019. "Brunner and Leijonhufvud: Friends or Foes?" The European Journal of the History of Economic Thought 26 (2): 231-270. doi:10.1080/09672567.2018.1555606.

Clower, R. 1965. “The Keynesian Counter-Revolution: A Theoretical Appraisal.” In The Theory of Interest Rates, edited by F. H. Hahn and F. P. R. Brechling. London, UK: Macmillan.

Cooper, R., and A. John. 1988. "Coordinating Coordination Failures in Keynesian Models." The Quarterly Journal of Economics 103 (3): 441-463. doi:10.2307/1885539.

De Vroey, M. 2016. A History of Macroeconomics from Keynes to Lucas and Beyond. Cambridge, UK: Cambridge University Press.

Diamond, P. 1982. “Aggregate Demand Management in Search Equilibrium.” Journal of Political Economy 90 (5): 881-894. doi:10.1086/261099.

Dos Santos Ferreira, R. 2014. "Mr. Keynes, the Classics and the New Keynesians: A Suggested Formalisation." The European Journal of the History of Economic Thought 21 (5): 801-838. doi:10.1080/09672567.2014.881896.

Fischer, S. 1977. "Long-Term Contracts, Rational Expectations, and the Optimal Money Supply Rule.” Journal of Political Economy 85 (1): 191-205. doi:10.1086/260551.

Gurley, J., and E. Shaw. 1960. Money in a Theory of Finance. Washington, DC: Brookings Institution.

Hicks, J. R. 1939. Value and Capital: An Inquiry into Some Fundamental Principles of Economic Theory. New York: Oxford University Press.

Howitt, P. 1984. "Information and Coordination: A Review Article." Economic Inquiry 22 (3): 429-446. doi:10.1111/j.1465-7295.1984.tb00697.x.

Howitt, P. 2002. "A Dictionary Article on Axel Leijonhufvud's 'on Keynesian Economics and the Economics of Keynes: A Study in Monetary Theory." In Dictionnaire des Grandes Oeuvres Economiques, edited by Michel De Vroey, Jérôme Lallement, Xavier Greffe. Paris, France: Dalloz editions.

Johnson, H. 1965. "Monetary Theory and Policy." In Surveys of Economic Theory, 1-45. London, UK: Palgrave Macmillan.

Kahn, R. 1976. "Unemployment as Seen by the Keynesians." In The Concept and Measurement of Involuntary Unemployment, edited by G. D. N. Worswick, 19-34. London: George Allen and Unwin.

Keynes, J. M. 1936. The General Theory of Employment, Interest and Money. London, UK: Macmillan.

Keynes, J. M. 1980. “The Collected Writings.” In The General Theory and after: A Supplement, vol. 29, edited by D. N. Moggridge. London, UK: Cambridge University Press for the Royal Economic Society. 
Leijonhufvud, A. 1967. "Keynes and the Keynesians: A Suggested Interpretation." The American Economic Review 57 (2): 401-410.

Leijonhufvud, A. 1968. On Keynesian Economics and the Economics of Keynes. Oxford, UK: Oxford University Press.

Leijonhufvud, A. 1969. Keynes and the Classics: Two Lectures. London, UK: Institute of Economic Affairs.

Leijonhufvud, A. 1983. "What Would Keynes Have Thought of Rational Expectations?" In Keynes and the Modern World, edited by D. Worswick and J. Trevithick. Cambridge: Cambridge University Press.

Leijonhufvud, A. 1988. "Did Keynes Mean Anything? Rejoinder to Yeager.” Cato Journal 8 (1): 209-217.

Leijonhufvud, A. 1989. Keynesian Economics: Past Confusions, Future Prospects. Korea Development Institute. https://www.kdi.re.kr/kdi_eng/publications/publication_view.jsp?pub_ no $=825$

Leijonhufvud, A. 1993. "Towards a Not-Too-Rational Macroeconomics." Southern Economic Journal 60 (1): 1-13. doi:10.2307/1059926.

Leijonhufvud, A. 1995. "Adaptive Behavior, Market Processes and the Computable Approach." Revue Économique 46 (6): 1497-1510. doi:10.2307/3502459.

Leijonhufvud, A. 1998. "Mr Keynes and the Moderns." The European Journal of the History of Economic Thought 5 (1): 169-188. doi:10.1080/10427719800000007.

Leijonhufvud, A. 2000. "What Would Keynes Have Thought of Rational Expectations?" In Macroeconomic Instability and Coordination: Selected Essays of Axel Leijonhufvud. Cheltenham UK: Edward Elgar Publishing.

Leijonhufvud, A. 2006. "Agent-Based Macro." In Handbook of Computational Economics, Vol. 2, chapter 36, edited by Leigh Tesfatsion and Kenneth Judd. Amsterdam, Netherlands: Elsevier Science, North Holland.

Morris, S., and H. S. Shin. 1997. "Approximate Common Knowledge and Co-ordination: Recent Lessons from Game Theory." Journal of Logic, Language and Information 6 (2): 171-190. doi:10.1023/A:1008270519000.

Morris, S., and H. S. Shin. 1995. "Informational Events that Trigger Currency Attacks." Working Paper 95-24, Federal Reserve Bank of Philadelphia.

Patinkin, D. 1948. "Price Flexibility and Full Employment." The American Economic Review 38 (4): 543-564.

Patinkin, D. 1965. Money, Interest and Prices: An Integration of Monetary and Value Theory. 2nd ed. New York, NY: Harper and Row.

Phelps, E. S., and J. B. Taylor. 1977. "Stabilizing Powers of Monetary Policy under Rational Expectations." Journal of Political Economy 85 (1): 163-190. doi:10.1086/260550.

Robinson, J. 1937. "Full Employment." In Essays in the Theory of Employment. London: Mcmillan.

Sims, C. 2003. "Implications of Rational Inattention." Journal of Monetary Economics 50 (3): 665-690. doi:10.1016/S0304-3932(03)00029-1.

Snowdon, B. 2004. "Outside the Mainstream: An Interview with Axel Leijonhufvud." Macroeconomic Dynamics 8 (1): 117-145. doi:10.1017/S1365100504030056.

Tobin, J. 1955. “A Dynamic Aggregative Model.” Journal of Political Economy 63 (2): 103-115. doi:10.1086/257652.

Tobin, J. 1956. "The Interest-Elasticity of Transactions Demand for Cash." The Review of Economics and Statistics 38 (3): 241-247. doi:10.2307/1925776.

Tobin, J. 1958. "Liquidity Preference as Behavior towards Risk." The Review of Economic Studies 25 (2): 65-86. doi:10.2307/2296205.

Trautwein, H.-M. 2020. "Leijonhufvud on New Keynesian Economics and the Economics of Keynes.” Oxford Economic Papers, gpaa013,. doi:10.1093/oep/gpaa013.

Woodford, M. 2002. "Imperfect Common Knowledge and the Effects of Monetary Policy." In Knowledge, Information, and Expectations in Modern Macroeconomics: In Honour of Edmund S. Phelps, edited by Philippe Aghion, Roman Frydman, Joseph Stiglitz, and Michael Woodford. Princeton, NJ: Princeton University Press. 